Asian-Australasian Journal of

Food Safety and Security

ISSN 2523-1073 (Print) 2523-2983 (Online)

www.ebupress.com/journal/aajfss

\title{
Article \\ Comparative study on nutritional status, food intake pattern and lifestyle between dialyzed and non-dialyzed kidney patients in Dhaka, Khulna and Rajshahi divisions of Bangladesh
}

\author{
Md Tanvir Islam ${ }^{1 *}$ and Nurun Nahar Mukta ${ }^{2}$ \\ ${ }^{1}$ Department of Public Health, American International University-Bangladesh, Banani, Dhaka, Bangladesh \\ ${ }^{2}$ Department of Nutrition and Food Technology, Jessore University of Science and Technology, Jessore, \\ Bangladesh
}

*Corresponding author: Md Tanvir Islam, Department of Public Health, American International UniversityBangladesh, Banani, Dhaka, Bangladesh. E-mail: tetratul@gmail.com

Received: 07 November 2017/Accepted: 19 November 2017/ Published: 21 November 2017

\begin{abstract}
Chronic kidney disease (CKD) is a worldwide public health problem. As per nephrologists' estimation, the CKD population grows at approximately 5\% annually and in 2022, over 29 million people will be afflicted with CKD in Bangladesh. The objective of this study was to compare nutritional status, food intake pattern, and lifestyle between dialyzed and non-dialyzed kidney patients in Bangladesh. It was a cross-sectional comparative study of patients aged 18 to 85 year old to compare nutritional status, food intake pattern, and lifestyle between dialyzed and non-dialyzed kidney patients. Sample was conducted in three divisions Dhaka, Khulna and Rajshahi in Bangladesh. Data on food intake pattern, height, weight, GFR, other diseases along with kidney disease, physical activity, smoking and socioeconomic status etc. were collected from fifteen clinical centers and sometimes from household via in-person interviews. A total of 244 patients aged were selected among them 152 people were dialyzed patients and 92 people were Non-dialyzed patients. We found a relationship among dietary food habit, lifestyle factors and health outcomes such as chronic kidney disease progression, heart disease and death. Patients had a mean monthly family income of 23683.46, a mean monthly expenditure on food of 3815.2 and a mean monthly expenditure on treatment of 13317.69. According to our findings, highest dialysis patients were sedentary than non-dialysis patients were active at their active life (20-40 Years). From this study it was investigated that, $41.0 \%$ patients have not changed their addiction habit after diagnosis, where $20.1 \%$ dialysis patients and $20.9 \%$ non-dialysis patients have not changed their addiction habit totally. Another significant finding of this study was that dialysis patients had poor consumption from 16 groups. It can be highlighted that, the prevalence of the diseases were higher in urban people than rural people. This study suggests that additional research is needed to investigate the optimal dietary recommendations and body mass index levels to prevent disease progression and poor outcomes among individuals with CKD. The prevalence of HD-CKD and NDD-CKD can be said to be SES dependent. Chronic kidney disease and its complications, which involve most organ systems, can be prevented, but awareness and use of accurate methods are needed to enable timely diagnosis.
\end{abstract}

Keywords: chronic kidney disease; nutritional status; food intake pattern; lifestyle

\section{Introduction}

Patients suffering from renal disease in the country are approximately 18-20 million. As per nephrologists' estimates, the chronic kidney disease (CKD) population grows at approximately 5\% annually and in 2022, over 29 million people will be afflicted with CKD in Bangladesh. With the increase of diabetes and hypertension, the prevalence of chronic kidney disease (CKD) is also alarmingly going up particularly in disadvantageous population. Chronic kidney disease is defined as either kidney damage or glomerular filtration rate 
(GFR) $<60 \mathrm{~mL} / \mathrm{min} / 1.73 \mathrm{~m}^{2}$ for $\geq 3$ months. Kidney damage is defined as pathologic abnormalities in blood or urine tests or imaging studies (Anand et al., 2014). Staging of CKD is based on estimation of renal function by GFR. GFR is calculated from serum creatinine by Cockcroft-Gault and MDRD equations. Some study showed that there were a significant number of patients with normal serum creatinine level who had abnormal GFR with Cockcroft-Gault values $\leq 50 \mathrm{~mL} / \mathrm{min}$ (Duncan et al., 2001). Non-dialysis Dependent Chronic Kidney Disease (NDD-CKD) is a designation used to encompass the status of those persons with an established CKD who do not yet require the life-supporting treatments for renal failure known as renal replacement therapy. According to the 2010 Global Burden of Disease study chronic kidney disease was ranked 27th in the list of causes of total number of global deaths in 1990 (age-standardized annual death rate of 15.7 per 100 000), but rose to 18th in 2010 (annual death rate 16.3 per 100 000) (Lozano et al., 2013). Chronic kidney disease (CKD) prevalence is three to five times higher in the Bangladeshi population compared with other ethnic groups in the UK (WHO, 2012). The International Diabetes Federation (IDF) estimates that the diabetic population of Bangladesh will be eleven million by 2030. Patients suffering from renal disease in the country are approximately 18-20 million. As per nephrologists' estimates, the CKD population grows at approximately 5\% annually and in 2022, over 29 million people will be afflicted with CKD in Bangladesh. People living with end stage renal diseases (ESRD) in the country are estimated to be $0.8-1$ million and $~ 40,000$ deaths occur annually due to lack of treatment (Jha et al., 2012). Chronic kidney disease imposes substantial economic burden on affected individuals, especially in developing countries. About $2-3 \%$ of the health-care expenditure in developed nations is used to provide treatment for patients with end-stage kidney disease even though they account for $0.1-0.2 \%$ of the total population; in 2010 treatment costs accounted for $6.3 \%$ of the Medicare budget in the USA, $4.1 \%$ of the total health-care budget in Japan in 1996, and 3.24\% of national health expenditure in South Korea in 2004 (deBritoAshurst et al., 2011). Chronic kidney disease (CKD) has numerous causes. The most common causes of CKD are diabetes mellitus and long-term, uncontrolled hypertension (Jha et al., 2012). The principal causes of chronic kidney disease in low income countries are chronic glomerulonephritis and interstitial nephritis reflecting the high prevalence of bacterial, viral, and parasitic infections that can affect the kidneys. However, diabetes causes 9.1 to 29.9 percent of the cases of end stage renal disease, and hypertension leads to 13 to 21 percent of the cases in the same countries (Barsoum, 2006). The diet for patients with end-stage kidney disease who are on dialysis is usually high in protein and low in sodium, potassium, and phosphorus. Fluid intake is also restricted. Protein needs are higher in patients with ESRD due to losses that occur during dialysis. The recommended dietary protein intake for clinically stable maintenance hemodialysis patients is $1.2 \mathrm{~g} / \mathrm{kg}$ body weight $/ \mathrm{d}$, and $1.2-1.3 \mathrm{~g} / \mathrm{kg}$ body weight $/ \mathrm{d}$ for individuals on peritoneal dialysis, $50 \%$ of which should come from sources high in biological value. Nutrition counseling should be intensive initially and provided every 1 or 2 months thereafter. If nutrient intake appears inadequate, malnutrition is apparent or adverse events or illnesses threaten nutritional status, counseling should be increased. The National Kidney Foundation clinical practice guidelines for nutrition in chronic renal failure suggest that patients achieve $100 \%$ of the Dietary Reference Intakes (DRI) for vitamins $A, C, E, K$, thiamin $\left(B_{1}\right)$, riboflavin $\left(B_{2}\right)$, pyridoxine $\left(B_{6}\right)$, vitamin $B_{12}$, and folic acid, as well as $100 \%$ of the DRI for copper and zinc (Kopple, 2001). Nutritional status should be assessed, and every patient with ESRD should receive a diet plan. For patients who have progressed to the need for dialysis, morbidity and mortality can be reduced and quality of life enhanced through adherence to an appropriate dietary and medical regimen, along with regular physical activity. On the other hand, for nondialyzed patient it is recommended that, the kidney diet must consists of low amounts of protein and should be limited at least to the recommended intake of $0.7-0.8 \mathrm{~g} / \mathrm{kg}$ ideal body weight $/$ day. If the GFR decreases below the value of 60 to $50 \mathrm{ml} / \mathrm{min}$ (stages 3 to 5), a more intense protein restriction is recommended. To prevent protein malnutrition, essential keto acids/amino acids are often taken as supplementation to protein-restricted diets (Agarwal et al., 2006). This study was conducted to find out the prevalence of CKD and its association with risk factors as there was no exact data before this tiny endeavor that has been inaugurated in Bangladesh.

\section{Materials and Methods}

\subsection{Study design and sample collection}

Total 244 patients were selected for the study. The study was carried out from January, 2015 to October, 2015 which included study design, questionnaire preparation, literature review, data collection, data analysis and written up. Among the selected patients 152 were dialyzed patients and 92 were Non-dialyzed patients. Firstly, 120 CKD patients were interviewed from several hospitals of Dhaka and Rajshahi division namely Dhaka CMH, BSMMU, BARDEM, Marks Medical Hospital, National Kidney Foundation, Rajshahi Medical College, Ebne-Sina Clinic and 79 CKD patients were interviewed from several hospitals of Khulna division namely Khulna Medical College Hospital, Shohid Sheikh Abu Naser Medical Center, Queens Hospital Jessore, Jessore 
Sadar Hospital. From Rajshahi 45 CKD patients were interviewed. A simple random sampling design following a simple random sampling procedure was done to choose the study area and a total of 244 patients ranging from 18 to 85 years had been studied. Out of the chosen 244 patients, 97 were females and 147 were males.

\subsection{Nutritional analysis}

The study was cross-sectional comparative study in design comparing the dietary intake pattern, lifestyle, nutritional status of dialyzed and non-dialyzed patient. For dietary assessment, nutrition-related indicator such as- 30-days diet history interview were conducted.

\subsection{Determination of dietary food intake pattern}

Information about food intake pattern on cereals, white roots and tubers, meat/fish, egg, legumes/nuts and seeds, milk/ milk products, fats and oils, sweets, spices/condiments/beverages, sweet fruits, citrus fruits, leafy vegetables, non-leafy vegetables, colored vegetables etc were collected. Participants completed 30-days diet history. Interviewers recorded their food and beverage intake, food habit, water drinking, salt intake. In the 30days diet history, the respondent is asked to remember and report all the foods and beverages consumed in the 30-days.

\subsection{Lifestyle related information}

Lifestyle of participants was determined by assessing their physical activity, walking time, working time, sleeping time, addiction habits.

\subsection{Socio-economic information}

Socio-economic information including age, educational qualification, occupation, monthly income and expenditure, monthly expenditure on food items, total family members for different usages information were collected by person to person interview with target patients. Disease Pattern Information of Target Population: Suffering from disease within last 90 days, name of the diseases, and number of disease-suffered patients; treatment cost, family member suffering from CKD, first confirmation and first detection of disease, frequency of measuring blood glucose level, creatinine level, GFR level and blood pressure level.

\subsection{Anthropometric information}

To determine nutritional status of dialyzed and non-dialyzed kidney patient's age, height, weight, BMI, GFR level of patients were recorded.

\subsection{Data analysis}

Information from finally checked questionnaires were entered in a data entry form using Statistical Package for Social Science (SPSS) Windows version 16 software and data entry were carefully done to avoid errors. The data were analyzed by applying percentages, crosstabs, chi-square test, standard deviations, means and correlation test and regression analysis. Comparative analysis was undertaken to investigate nutritional status, lifestyle, socioeconomic information, food intake pattern, clinical findings of children and anthropometric status.

\section{Results}

\subsection{Socio-demographic status}

There are total $65.6 \%$ patients from urban area, where $60.2 \%$ are male and $85.2 \%$ are muslim. For dialysis patients, $45.5 \%$ are from urban, $39.3 \%$ are male and $54.9 \%$ are muslim. And for non-dialysis patients, $20.1 \%$ are from urban, $20.9 \%$ are male and $30.3 \%$ are muslim (Table 1 ).

Table1. Distribution of Socio-demographic status of dialysis and non-dialysis kidney patients.

\begin{tabular}{|c|c|c|c|c|c|c|}
\hline \multirow{2}{*}{$\begin{array}{l}\text { Socio-demographic } \\
\text { status }\end{array}$} & & \multicolumn{2}{|c|}{ Type of kidney disease } & \multirow[t]{2}{*}{ Total } & \multirow[t]{2}{*}{ Chi Square } & \multirow[t]{2}{*}{ P value } \\
\hline & & Dialysis & Non-dialysis & & & \\
\hline \multirow[t]{2}{*}{ Location } & Rural & $16.8 \%(41)$ & $17.6 \%(43)$ & $34.4 \%(84)$ & 9.918 & $<.01^{* *}$ \\
\hline & Urban & $45.5 \%(111)$ & $20.1 \%(49)$ & $65.6 \%(160)$ & & \\
\hline Total & & $62.30 \%(152)$ & $37.70 \%(92)$ & $100 \%(244)$ & & \\
\hline \multirow[t]{2}{*}{ Sex } & Male & $39.3 \%(96)$ & $20.9 \%(51)$ & $60.2 \%(147)$ & 4.427 & $<.05^{*}$ \\
\hline & Female & $23.0 \%(56)$ & $16.8 \%(41)$ & $39.8 \%(97)$ & & \\
\hline Total & & $62.30 \%(152)$ & $37.70 \%(92)$ & $100 \%(244)$ & & \\
\hline \multirow[t]{3}{*}{ Religion } & Muslim & $54.9 \%(134)$ & $30.3 \%(74)$ & $85.2 \%(208)$ & 2.718 & 0.25 \\
\hline & Hindu & $7.0 \%(17)$ & $7.0 \%(17)$ & $13.9 \%(34)$ & & \\
\hline & Christian & $0.4 \%(1)$ & $0.4 \%(1)$ & $0.8 \%(2)$ & & \\
\hline Total & & $62.30 \%(152)$ & $37.70 \%(92)$ & $100 \%(244)$ & & \\
\hline
\end{tabular}




\subsection{Education}

Total $4.5 \%$ patients were illiterate, $26.2 \%$ attended less than primary education, $2.5 \%$ competed primary education, $10.2 \%$ attended class VI to X, 9.8\% completed SSC, $22.1 \%$ completed HSC, $23.0 \%$ completed above HSC, and $1.6 \%$ completed Hafizia, where in Dialysis patients, $1.2 \%$ patients were illiterate, $12.7 \%$ attended less than primary education, $2.0 \%$ competed primary education, $5.3 \%$ attended class VI to X, $6.6 \%$ completed SSC, $16.4 \%$ completed HSC, $16.4 \%$ completed above HSC, and $1.6 \%$ completed Hafizia, and in Non-dialysis patients, $3.3 \%$ patients were illiterate, $13.5 \%$ attended less than primary education, $0.4 \%$ competed primary education, $4.9 \%$ attended class VI to X, 3.3\% completed SSC, 5.7\% completed HSC, $6.6 \%$ completed above HSC, and none of Non-dialysis patient completed Hafizia. The Chi-square value is 16.03 and with $7 \mathrm{df}$, the $\mathrm{p}$ value stands 0.0248 which is $<0.05$ and it is significant (Figure 1).

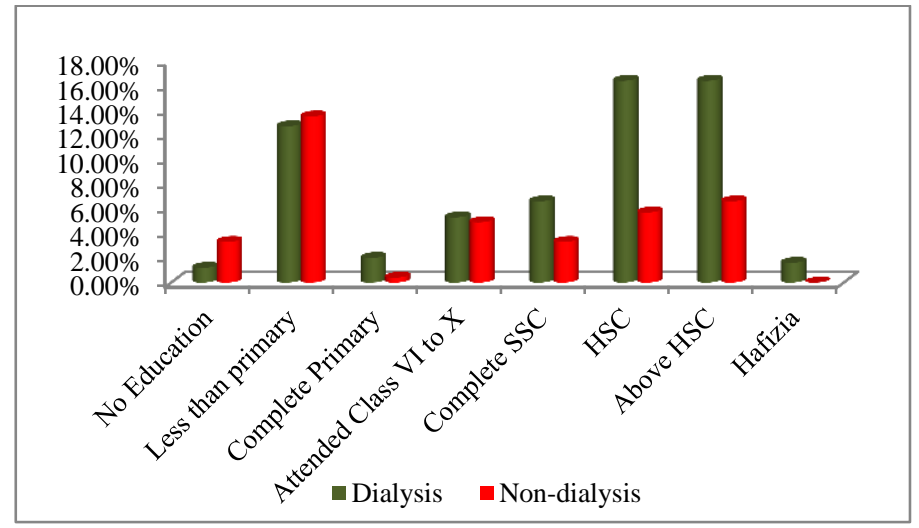

Figure 1. Percentage distribution of patients according to the education.

\subsection{Socio-economic status of chronic kidney disease patients}

The mean value for total family member is 4.5041 , total room in house is 3.4959 and total land is 83.9908 where the std. deviations for total family member are 1.54093, total room in house is 1.91055 , and total land is 108.77819 (Table 2).

Table 2. Mean and std. deviation value distribution for socio-economic status of chronic kidney disease patients.

\begin{tabular}{lll}
\hline Socio-economic status & Mean & Std. Deviation \\
\hline Total family member & 4.5041 & 1.54093 \\
Total room in house & 3.4959 & 1.91055 \\
Total land (decimal) & 83.9908 & 108.77819 \\
\hline
\end{tabular}

\subsection{Economic status}

The mean value is 10451 for monthly personal income, 34361 for monthly family income, 7269.7 for monthly expenditure on food, 19953 for monthly expenditure on treatment and 31006 for total monthly expenditure, where highest standard deviation stands beside monthly personal income 28552.34236 , and lowest stands beside monthly expenditure on food 3815.26907 (Table 3).

Table 3. Mean and std. deviation distribution for economic status of chronic kidney disease patients and their family.

\begin{tabular}{lll}
\hline Economic status & Mean & Std. Deviation \\
\hline Monthly personal income & 10451 & 28552.34236 \\
Monthly family income & 34361 & 23683.46320 \\
Monthly expenditure food & 7269.7 & 3815.26907 \\
Monthly expenditure treatment & 19953 & 13317.69268 \\
Monthly expenditure total & 31006 & 26395.90478 \\
\hline
\end{tabular}




\subsection{Percentage of monthly expenditure on food}

Total $48.8 \%$ patient's family expend quarter of their total family income , $48.8 \%$ patient's family expend half of their total family income, $2.5 \%$ patient's family expend two-third of their total family income where in Dialysis patients, $29.1 \%$ patient's family expend quarter of their total family income, $32.0 \%$ patient's family expend half of their total family income, $1.2 \%$ patient's family expend two-third of their total family income and in NonDialysis patients, $19.7 \%$ patient's family expend quarter of their total family income , $16.8 \%$ patient's family expend half of their total family income, $1.2 \%$ patient's family expend two-third of their total family income. The Chi-square score is 5.061 and with $2 \mathrm{df}$ the p-value is 0.0796 which is not significant (>.05) (Figure 2).

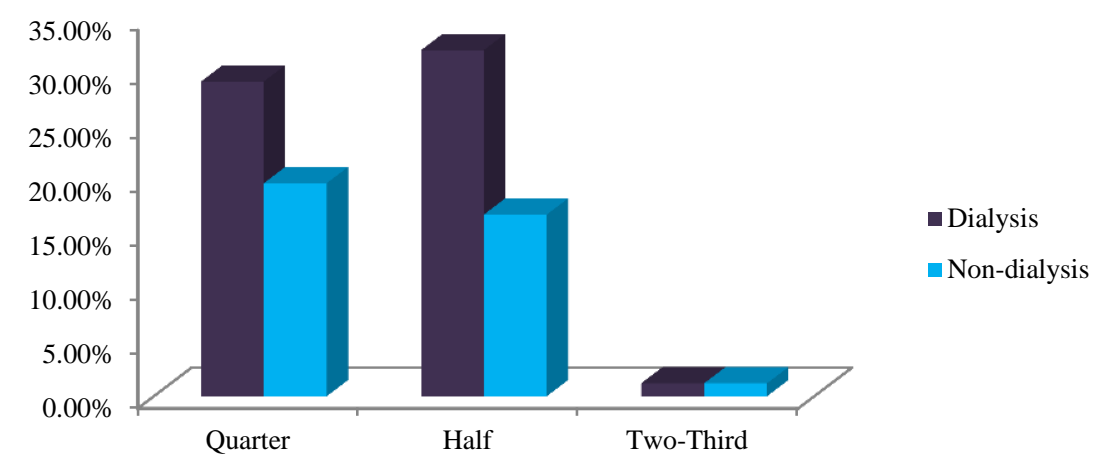

Figure 2. Percentage distribution of patients according to the monthly expenditure on food.

\subsection{Average monthly expenditure on food}

$25.0 \%$ patients had monthly expenditure on food up to 1000 taka, $59.4 \%$ had monthly expenditure on food between 1001 taka to 2500 taka, $15.6 \%$ had monthly expenditure on food more than 2500 taka, where in Dialysis patients, $11.1 \%$ patients had monthly expenditure on food up to 1000 taka, $36.1 \%$ had monthly expenditure on food between 1001 taka to 2500 taka, $15.2 \%$ had monthly expenditure on food more than 2500 taka and in Non-dialysis patients, $13.9 \%$ patients had monthly expenditure on food up to 1000 taka, $23.4 \%$ had monthly expenditure on food between 1001 taka to 2500 taka, $0.4 \%$ had monthly expenditure on food more than 2500 taka. The Chi-square score is 8.506 and with $2 \mathrm{df}$ the p-value is 0.0142 which is significant (<.05) (Figure $3)$.

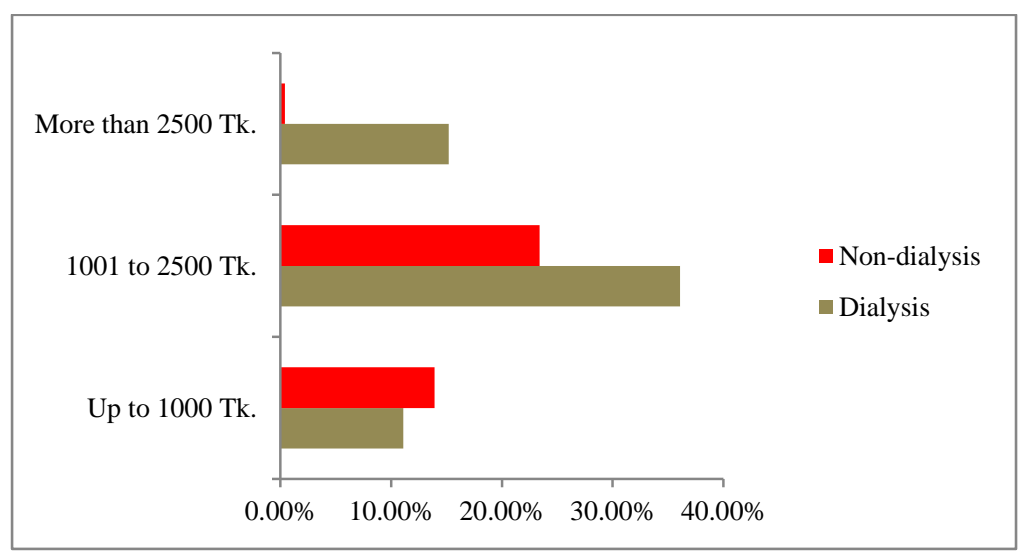

Figure 3. Percent distribution of patients according to the amount of average monthly expenditure on food.

\subsection{Socio-demographic status of different stages of kidney patients}

There are total $60.2 \%$ are male and $39.8 \%$ are female where $65.6 \%$ patients are from urban area, $34.4 \%$ are from rural area, $85.2 \%$ are Muslim and $13.9 \%$ patients are Hindu. For stage-5 patients, $45.5 \%$ are from urban, 39.3\% are male and $54.9 \%$ are Muslim (Table 4). 
Table 4. Distribution of socio-demographic status of different stages of kidney patients basis on glomerular filtration rate.

\begin{tabular}{|c|c|c|c|c|c|c|c|c|c|}
\hline \multirow{2}{*}{$\begin{array}{l}\text { Socio- } \\
\text { demographic } \\
\text { status }\end{array}$} & & \multicolumn{5}{|c|}{ Glomerular filtration rate (GFR) } & \multirow[t]{2}{*}{ Total } & \multirow{2}{*}{$\begin{array}{l}\text { Chi } \\
\text { Square }\end{array}$} & \multirow[t]{2}{*}{ P value } \\
\hline & & $\begin{array}{l}\text { Stage } \\
(60-89)\end{array}$ & 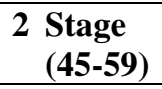 & $\begin{array}{c}\text { 3A Stage } \\
(30-44) \\
\end{array}$ & $\begin{array}{c}\text { 3B Stage } \\
(15-29)\end{array}$ & $\begin{array}{l}4 \text { Stage } 5 \text { (less } \\
\text { than 15) }\end{array}$ & & & \\
\hline \multirow[t]{2}{*}{$\overline{\text { Sex }}$} & Male & $4.1 \%$ & $12.7 \%$ & $2.5 \%$ & $1.6 \%$ & $39.3 \%$ & $60.2 \%$ & 15.87 & $<.01 * *$ \\
\hline & Female & $0.8 \%$ & $7.4 \%$ & $7.4 \%$ & $1.2 \%$ & $23.0 \%$ & $39.8 \%$ & & \\
\hline \multirow[t]{2}{*}{ Location } & Rural & $2.5 \%$ & $8.6 \%$ & $4.5 \%$ & $2.0 \%$ & $16.8 \%$ & $34.4 \%$ & 12.20 & $<.05^{*}$ \\
\hline & Urban & $2.5 \%$ & $11.5 \%$ & $5.3 \%$ & $0.8 \%$ & $45.5 \%$ & $65.6 \%$ & & \\
\hline \multirow[t]{3}{*}{ Religion } & Muslim & $4.5 \%$ & $14.8 \%$ & $8.6 \%$ & $2.5 \%$ & $54.9 \%$ & $85.2 \%$ & 7.363 & 0.49 \\
\hline & Hindu & $0.4 \%$ & $4.9 \%$ & $1.2 \%$ & $0.4 \%$ & $7.0 \%$ & $13.9 \%$ & & \\
\hline & Christian & $0.0 \%$ & $0.4 \%$ & $0.0 \%$ & $0.0 \%$ & $0.4 \%$ & $0.8 \%$ & & \\
\hline
\end{tabular}

\subsection{Family's kidney disease history}

Total $39.8 \%$ patient's family member suffered at kidney disease, $60.2 \%$ patient's family member not suffered at kidney disease, where in Dialysis patients, $24.2 \%$ patient's family member suffered at kidney disease, $38.1 \%$ patient's family member not suffered at kidney disease, and in Non-dialysis patients, $15.6 \%$ patient's family member suffered at kidney disease, $22.1 \%$ patient's family member not suffered at kidney disease. The Chisquare score is 4.148 and with $1 \mathrm{df}$ the p-value is 0.0416 which is significant $(<.05)$ (Figure 4).

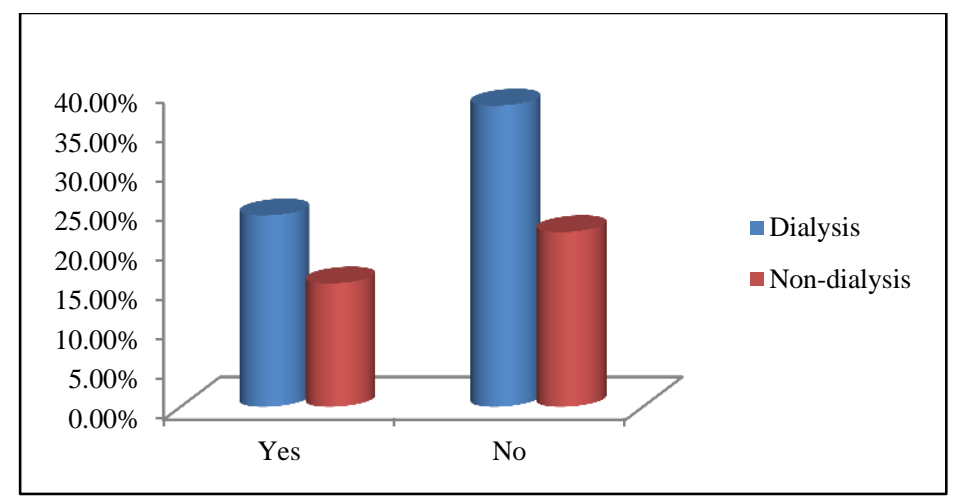

Figure 4. Percentage distribution of patients according to anyone of family suffered at kidney disease.

\subsection{Multi disease condition among kidney patients}

Total $15.2 \%$ dialysis patients have no other disease, $9.4 \%$ have diabetes, $12.7 \%$ have hypertension and $20.5 \%$ have other diseases where $16.4 \%$ non-dialysis patients have no other disease. Again, $18.9 \%$ male patients have no other disease, $11.1 \%$ hypertension, and $16.4 \%$ have other diseases where $12.7 \%$ female patients have no other disease. $18.9 \%$ male patients have no other disease where $12.7 \%$ female patients have no other disease. 26.2\% Muslim patients have no other disease and 26.6\% Muslim patients have other disease (Table 5).

Table 5. Percent distribution of multi disease condition among kidney patients.

\begin{tabular}{|c|c|c|c|c|c|c|c|c|}
\hline & & \multicolumn{6}{|c|}{ Multi-disease condition } & \multirow[t]{2}{*}{ Total } \\
\hline & & $\begin{array}{l}\text { No Other } \\
\text { Disease }\end{array}$ & Diabetes & Hypertension & $\begin{array}{l}\text { Cardiovascular } \\
\text { disease }\end{array}$ & Asthma & Others & \\
\hline \multirow{2}{*}{$\begin{array}{l}\text { Type of } \\
\text { Kidney } \\
\text { Disease }\end{array}$} & Dialysis & 15.2 & 9.4 & 12.7 & 3.3 & 1.2 & 20.5 & 62.3 \\
\hline & $\begin{array}{l}\text { Non- } \\
\text { dialysis }\end{array}$ & 16.4 & 4.9 & 6.1 & 0.8 & 1.2 & 8.2 & 37.7 \\
\hline \multirow[t]{2}{*}{ Sex } & Male & 18.9 & 9.8 & 11.1 & 2.9 & 1.2 & 16.4 & 60.2 \\
\hline & Female & 12.7 & 4.5 & 7.8 & 1.2 & 1.2 & 12.3 & 39.8 \\
\hline \multirow[t]{2}{*}{ Location } & Rural & 13.9 & 7.0 & 8.2 & 0.4 & 0.4 & 4.5 & 34.4 \\
\hline & Urban & 17.6 & 7.4 & 10.7 & 3.7 & 2.0 & 24.2 & 65.6 \\
\hline \multirow[t]{3}{*}{ Religion } & Muslim & 26.2 & 11.9 & 14.3 & 4.1 & 2.0 & 26.6 & 85.2 \\
\hline & Hindu & 4.5 & 2.5 & 4.5 & 0.0 & 0.4 & 2.0 & 13.9 \\
\hline & Christian & 0.8 & 0.0 & 0.0 & 0.0 & 0.0 & 0.0 & 0.8 \\
\hline
\end{tabular}


3.10. Patients (dialysis and non-dialysis) according to physical activity

Total $68.9 \%$ patients were sedentary, $20.5 \%$ moderate and $10.7 \%$ patient's active as their perception, where total $59.4 \%$ patients were sedentary, $25.0 \%$ moderate and $15.6 \%$ patients active at their active life (20-40 Years). Highest $40.2 \%$ dialysis patients were sedentary 9.8\% Non-dialysis patients were active at their active life (20-40 Years) (Table 6).

Table 6. Distribution of patients (dialysis and non-dialysis) according to physical activity.

\begin{tabular}{|c|c|c|c|c|c|c|}
\hline \multirow[t]{2}{*}{ Physical activity } & & \multicolumn{2}{|c|}{ Type of kidney disease } & \multirow[t]{2}{*}{ Total } & \multirow{2}{*}{$\begin{array}{l}\text { Chi } \\
\text { Square }\end{array}$} & \multirow[t]{2}{*}{$P$ value } \\
\hline & & Dialysis & Non-dialysis & & & \\
\hline \multirow{3}{*}{$\begin{array}{l}\text { Perception of } \\
\text { respondent }\end{array}$} & Sedentary & $43.0 \%(105)$ & $25.8 \%(63)$ & $68.9 \%(168)$ & \multirow[t]{3}{*}{9.207} & \multirow[t]{3}{*}{$<.05^{*}$} \\
\hline & Moderate & $15.2 \%(37)$ & $5.3 \%(13)$ & $20.5 \%(50)$ & & \\
\hline & Active & $4.1 \%(10)$ & $6.6 \%(16)$ & $10.7 \%(26)$ & & \\
\hline \multirow{3}{*}{$\begin{array}{l}\text { Active life (20-40 } \\
\text { years) }\end{array}$} & Sedentary & $40.2 \%(98)$ & $19.3 \%(47)$ & $59.4 \%(145)$ & \multirow[t]{3}{*}{12.48} & \multirow[t]{3}{*}{$<.01^{* *}$} \\
\hline & Moderate & $16.4 \%(40)$ & $8.6 \%(21)$ & $25.0 \%(61)$ & & \\
\hline & Active & $5.7 \%(14)$ & $9.8 \%(24)$ & $15.6 \%(38)$ & & \\
\hline
\end{tabular}

\subsection{Patients (dialysis and non-dialysis) according to presence of addiction habit}

Total $50.0 \%$ patients had addiction habit and $50.0 \%$ had no addiction habit before diagnosis of kidney disease. But, $32.0 \%$ patients have addiction habit until now after diagnosis where $68.0 \%$ have not. $33.6 \%$ dialysis patients and $16.4 \%$ non-dialysis patients had addiction habit before diagnosis of kidney disease where $19.3 \%$ dialysis patients and $12.7 \%$ non-dialysis patients had present addiction habit (Table 7).

Table 7. Distribution of patients (dialysis and non-dialysis) according to presence of addiction habit.

\begin{tabular}{|c|c|c|c|c|c|c|}
\hline \multirow{2}{*}{$\begin{array}{l}\text { Presence of } \\
\text { addiction habit }\end{array}$} & & \multicolumn{2}{|c|}{ Type of kidney disease } & \multirow[t]{2}{*}{ Total } & \multirow[t]{2}{*}{ Chi Square } & \multirow[t]{2}{*}{$P$ value } \\
\hline & & Dialysis & Non-dialysis & & & \\
\hline \multirow[t]{2}{*}{ Before Diagnosis } & Yes & $33.6 \%(82)$ & $16.4 \%(40)$ & $50.0 \%(122)$ & 2.513 & $>.05$ \\
\hline & No & $28.7 \%(70)$ & $21.3 \%(52)$ & $50.0 \%(122)$ & & \\
\hline \multirow[t]{2}{*}{ After Diagnosis } & Yes & $19.3 \%(47)$ & $12.7 \%(31)$ & $32.0 \%(78)$ & 1.052 & $>.05$ \\
\hline & No & $43.0 \%(105)$ & $25.0 \%(61)$ & $68.0 \%(166)$ & & \\
\hline
\end{tabular}

\subsection{Patients (Dialysis and Non-dialysis) according to the type of addiction habit}

Total $45.1 \%$ patients were addicted to smoking tobacco, $45.1 \%$ were addicted to non-smoking tobacco and $9.8 \%$ were addicted to both smoking and non-smoking tobacco at past, where total $32.1 \%$ patients are addicted to smoking tobacco, $64.1 \%$ are addicted to non-smoking tobacco, $3.8 \%$ are addicted to both smoking and nonsmoking tobacco. $32.0 \%$ dialysis patients were addicted to smoking tobacco, $28.7 \%$ were addicted to nonsmoking tobacco and $6.6 \%$ were addicted to both smoking and non-smoking tobacco at past. But, at present, $17.9 \%$ dialysis patients were addicted to smoking tobacco, $42.3 \%$ dialysis patients were addicted to nonsmoking tobacco and $21.8 \%$ non-dialysis patients were addicted to non-smoking tobacco (Table 8).

Table 8. Distribution of patients (Dialysis and Non-dialysis) according to the type of addiction habit.

\begin{tabular}{|c|c|c|c|c|c|c|}
\hline \multirow{2}{*}{$\begin{array}{l}\text { Type of addiction } \\
\text { habit }\end{array}$} & & \multicolumn{2}{|c|}{ Type of kidney disease } & \multirow[t]{2}{*}{ Total } & \multirow{2}{*}{$\begin{array}{l}\text { Chi } \\
\text { Square }\end{array}$} & \multirow[t]{2}{*}{ P value } \\
\hline & & Dialysis & Non-dialysis & & & \\
\hline \multirow[t]{3}{*}{ Past } & Smoking Tobacco & $32.0 \%(39)$ & $13.1 \%(16)$ & $45.1 \%(55)$ & 6.662 & $<.05^{*}$ \\
\hline & Non-smoking Tobacco & $28.7 \%(35)$ & $16.4 \%(20)$ & $45.1 \%(55)$ & & \\
\hline & $\begin{array}{l}\text { Both Smoking and } \\
\text { Non-smoking Tobacco }\end{array}$ & $6.6 \%(8)$ & $3.3 \%(4)$ & $9.8 \%(12)$ & & \\
\hline \multirow[t]{3}{*}{ Present } & Smoking Tobacco & $17.9 \%(14)$ & $14.1 \%(11)$ & $32.1 \%(25)$ & 5.246 & $>.05$ \\
\hline & Non-smoking Tobacco & $42.3 \%(33)$ & $21.8 \%(17)$ & $64.1 \%(50)$ & & \\
\hline & $\begin{array}{l}\text { Both Smoking and } \\
\text { Non-smoking Tobacco }\end{array}$ & $0.0 \%(0)$ & $3.8 \%(3)$ & $3.8 \%(3)$ & & \\
\hline
\end{tabular}

3.13. Patients (dialysis and non-dialysis) according to second hand smoking

Total $51.2 \%$ patients suffered from second hand smoking, $48.8 \%$ not suffered from second hand smoking, where in dialysis patients, $24.2 \%$ patients suffered from second hand smoking, $38.1 \%$ not suffered from second 
hand smoking, and in non-dialysis patients, $27.0 \%$ patients suffered from second hand smoking, $10.7 \%$ not suffered from second hand smoking. The Chi-square score is 4.864 and with $1 \mathrm{df}$ the p-value is 0.0274 which is significant (<.05) (Figure 5).

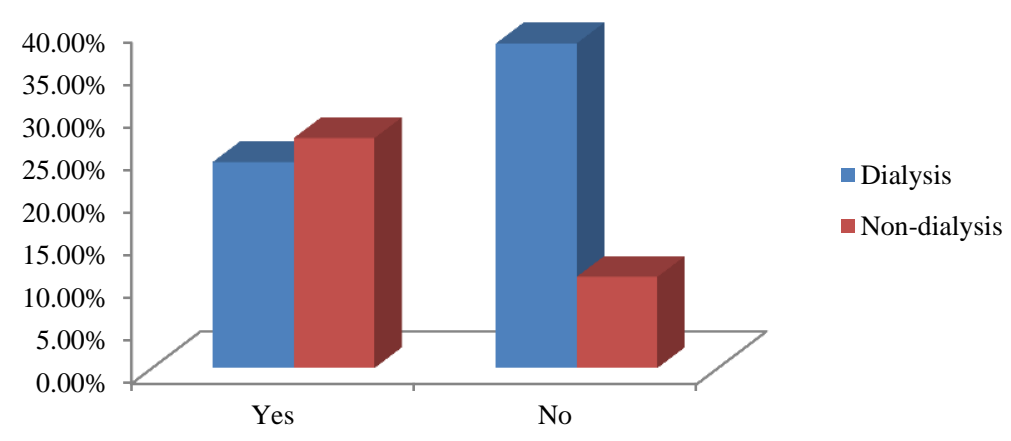

Figure 5. Percent distribution of patients (dialysis and non-dialysis) according to second hand smoking.

\subsection{Distribution of CKD patients according to change at habits after diagnosis}

Total $17.2 \%$ patients totally, $68.4 \%$ patients partially and $14.3 \%$ have not changed their food habit after diagnosis where the most $42.6 \%$ dialysis patients and $25.8 \%$ non-dialysis patients have changed food habit partially. On the other hand, total $13.9 \%$ patients totally, $48.0 \%$ patients partially and $31.1 \%$ have not changed their lifestyle after diagnosis where $35.2 \%$ dialysis patients partially and $20.9 \%$ non-dialysis patients have not changed their lifestyle totally. Again, total $23.0 \%$ patients totally, $36.1 \%$ patients partially and $41.0 \%$ have not changed their addiction habit after diagnosis, where $20.1 \%$ dialysis patients and $20.9 \%$ non-dialysis patients have not changed their addiction habit totally (Table 9).

Table 9. Distribution of CKD patients according to change at habits after diagnosis.

\begin{tabular}{|c|c|c|c|c|c|c|}
\hline \multirow{2}{*}{$\begin{array}{l}\text { Change of habit and } \\
\text { lifestyle after diagnosis }\end{array}$} & & \multicolumn{2}{|c|}{ Type of kidney disease } & \multirow[t]{2}{*}{ Total } & \multirow{2}{*}{$\begin{array}{l}\text { Chi } \\
\text { Square }\end{array}$} & \multirow[t]{2}{*}{$P$ value } \\
\hline & & Dialysis & Non-dialysis & & & \\
\hline \multirow[t]{3}{*}{ Food Habit } & Total & $11.5 \%(28)$ & $5.7 \%(14)$ & $17.2 \%(42)$ & 0.737 & $>.05$ \\
\hline & Partial & $42.6 \%(104)$ & $25.8 \%(63)$ & $68.4 \%(167)$ & & \\
\hline & No & $8.2 \%(20)$ & $6.1 \%(15)$ & $14.3 \%(35)$ & & \\
\hline \multirow[t]{3}{*}{ Lifestyle } & Total & $9.8 \%(24)$ & $4.1 \%(10)$ & $13.9 \%(34)$ & 8.878 & $<.05^{*}$ \\
\hline & Partial & $35.2 \%(86)$ & $12.7 \%(31)$ & $48.0 \%(117)$ & & \\
\hline & No & $17.2 \%(42)$ & $20.9 \%(51)$ & $38.1 \%(93)$ & & \\
\hline \multirow[t]{3}{*}{ Addiction Habit } & Total & $14.8 \%(36)$ & $8.2 \%(20)$ & $23.0 \%(56)$ & 14.79 & $<.01^{* *}$ \\
\hline & Partial & $27.5 \%(67)$ & $8.6 \%(21)$ & $36.1 \%(88)$ & & \\
\hline & No & $20.1 \%(49)$ & $20.9 \%(51)$ & $41.0 \%(100)$ & & \\
\hline
\end{tabular}

3.15. Distribution of food item consumption (among16 group) of dialysis and non-dialysis patients

Total $48.0 \%$ patients had poor consumption from 16 groups, $45.9 \%$ had acceptable consumption, $6.1 \%$ had higher acceptable consumption, where $29.9 \%$ Dialysis patients had poor consumption from 16 groups, $27.5 \%$ had acceptable consumption, $4.9 \%$ had higher acceptable consumption and $18.0 \%$ Non-dialysis patients had poor consumption from 16 groups, $18.4 \%$ had acceptable consumption, $1.2 \%$ had higher acceptable consumption. The Chi-square score is 6.294 and with $2 \mathrm{df}$ the p-value is 0.0429 which is significant $(<.05)$ (Figure 6). 


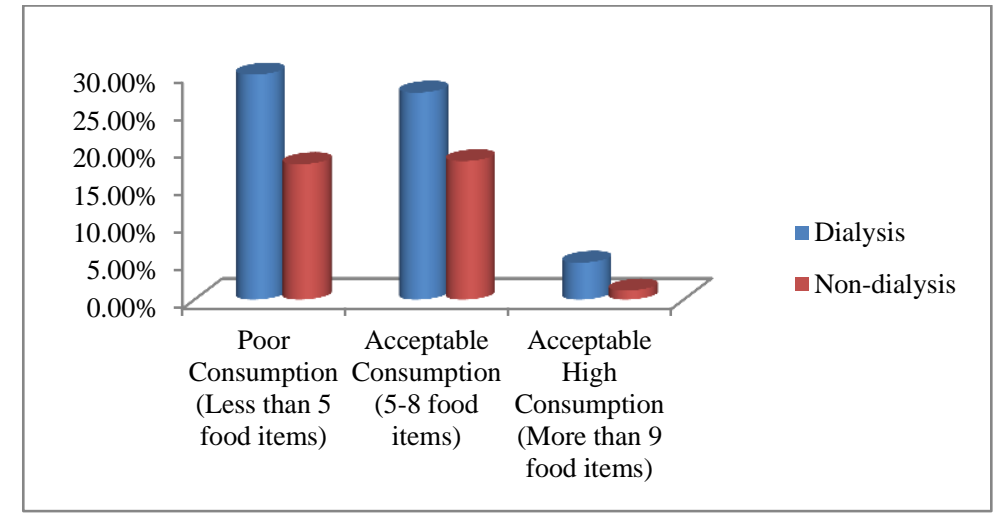

Figure 6. Percentage distribution of food item consumption (among16 group) of dialysis and non-dialysis patients.

\subsection{Distribution of food item consumption among kidney patients}

Total $48.0 \%$ patients were in poor consumption, $45.9 \%$ acceptable consumption, $6.1 \%$ acceptable high and $31.6 \%$ patients were in poor consumption, $25.4 \%$ acceptable consumption, $3.3 \%$ acceptable high among male and $16.4 \%$ patients were in poor consumption, $20.5 \%$ acceptable consumption, $2.9 \%$ acceptable high among female. The Chi-square score is 2.930 and with $2 \mathrm{df}$ the $\mathrm{p}$-value is 0.2310 which is not significant (>.05) (Figures 7 and 8).

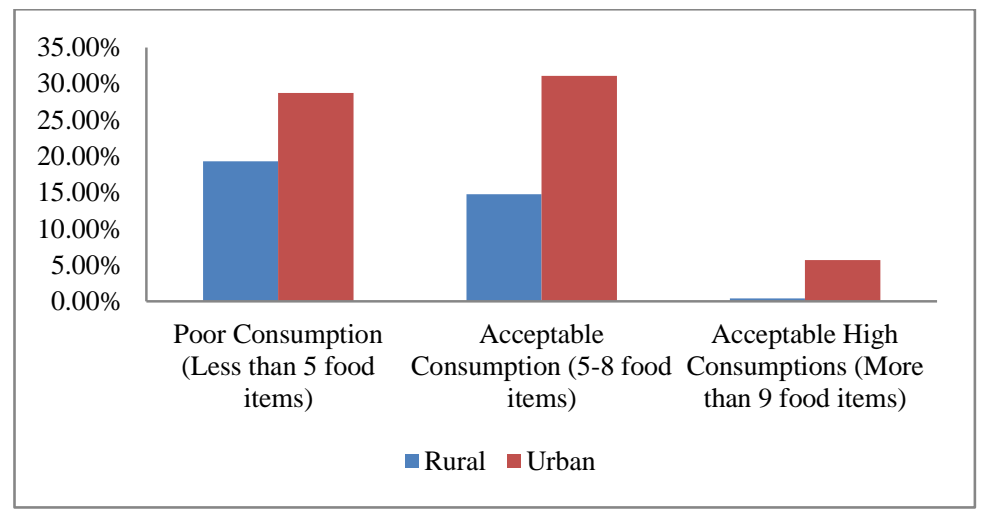

Figure 7. Percent distribution of food item consumption (among16 group) and location among kidney patients.

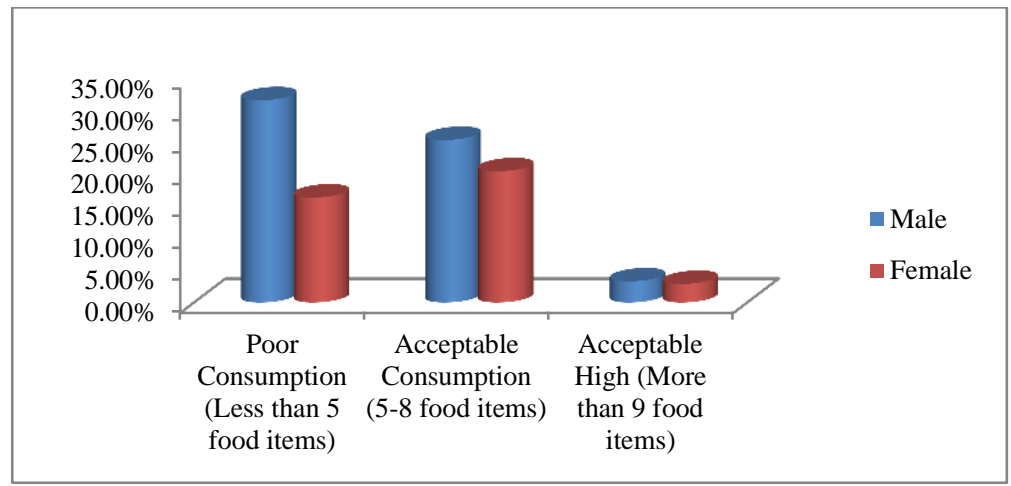

Figure 8. Percent distribution of food item consumption (among16 group) and sex among kidney patients.

\section{Discussion}

It can be highlighted that, the prevalence of the diseases were higher in urban people than rural people. This could be due to the affordability and purchasing power of calorie rich diet by individuals who earn high income hence they are more prone to the disease due to cholesterol derived from consumption of junk foods. Some most important observations were made in this cross- sectional study. Firstly, there were highest standard deviation stands beside monthly personal income 28552.34, and lowest stands beside monthly expenditure on food 3815.26. Patients had a mean monthly family income of 23683.46 , a mean monthly expenditure on food of 
3815.2 and a mean monthly expenditure on treatment of 13317.69. Especially HDD-CKD patient's families' experience direct loss of income and changes in consumption patterns because of the spending of household finances on care and welfare costs. According to this study, highest dialysis patients were sedentary than Nondialysis patients were active at their active life (20-40 Years). Total 68.9\% patients were sedentary, 20.5\% moderate and $10.7 \%$ active as their perception, where $59.4 \%$ patients were sedentary, $25.0 \%$ moderate and $15.6 \%$ patients active at their active life (20-40 Years). The nature of occupation could also be a factor responsible for the disease prevalence as observed in this study. It was observed that those engaged in heavy occupational activities at their active life (20-40 Years) had the lowest prevalence of the disease compared with those who engage in light occupational activity. The sedentary lifestyle experienced by those who engage in light occupational activities as observed mostly among the chief executives, bankers, office secretaries and directors in the study population possibly is one of the reasons for the high prevalence of the diseases among those of light occupational activities. From this observation it can be said that, occupational activity is associated with the development of CKD. The high exposure of both HDD-CKD and NDD-CKD patients to tobacco and other addiction habits (past, passive or current) could be related to the increasing worldwide tendency of end stage renal disease. This observation was in harmony with the findings of other researchers that Tobacco and end stage renal disease: a multicenter, cross-sectional study in Argentinian Northern Patagonia (Lozano et al., 2013; Anand et al., 2014; WHO, 2012 and deBrito-Ashurst et al., 2011). Use of tobacco in the form of smoking and chewing was significantly higher in CKD group than in the normal population (Jha et al., 2012; Barsoum, 2006; Agarwal et al., 2006). According to this study, 29.9\% Dialysis patients had poor consumption from 16 groups, $27.5 \%$ had acceptable consumption, $4.9 \%$ had higher acceptable consumption and $18.0 \%$ Non-dialysis patients had poor consumption from 16 groups, $18.4 \%$ had acceptable consumption, $1.2 \%$ had higher acceptable consumption. CKD patients should follow proper diet chart that help to slow down chronic kidney disease.

\section{Conclusions}

This study points to an alarmingly high rate of Chronic Kidney Diseases in Bangladesh. It can be concluded that HDD-CKD and NDD-CKD are consequences of the level of the socio-economic state of the individual. Prevention programs will function best as part of national non-communicable disease strategies, with the involvement of general practitioners.

\section{Conflict of Interest}

None to declare.

\section{References}

Agarwal R, AR Rizkala, B Bastani, MO Kaskas, DJ Leehey and A Besarab, 2006. A randomized controlled trial of oral versus intravenous iron in chronic kidney disease: protein-restricted diets supplemented with keto/amino acids. Consensus statement from the international advisory board meeting. Am. J. Nephrol., 26: 445-454.

Anand S, MA Khanam, J Saquib, N Saquib, T Ahmed, DS Alam and GM Chertow, 2014. High prevalence of chronic kidney disease in a community survey of urban Bangladeshis: a cross-sectional study| NOVA. The University of Newcastle's Digital Repository.

Barsoum RS, 2006. Chronic kidney disease in the developing world. The New England Journal of Medicine, 354: 997-999.

deBrito-Ashurst I, L Perry, TAB Sanders, JE Thomas, MM Yaqoob and H Dobbie, 2011. Barriers and facilitators of dietary sodium restriction amongst Bangladeshi chronic kidney disease patients. Journal of Human Nutrition and Dietetics, 24: 86-95.

Duncan L, J Heathcote, O Djurdjev and A Levin, 2001. Screening for renal disease using serum creatinine: who are we missing? Nephrology Dialysis Transplantation, 16: 1042-1046.

Jha V, AYM Wang and H Wang, 2012. The impact of CKD identification in large countries: the burden of illness. Nephrology Dialysis Transplantation, 27: 32-38.

Kopple JD, 2001. National kidney foundation K/DOQI clinical practice guidelines for nutrition in chronic renal failure. American Journal of Kidney Diseases, 37: S66-S70.

Lozano R, M Naghavi, K Foreman, S Lim, K Shibuya, V Aboyans and M Cross, 2013. Global and regional mortality from 235 causes of death for 20 age groups in 1990 and 2010: a systematic analysis for the Global Burden of Disease Study 2010. The Lancet, 380: 2095-2128.

WHO, 2012. Health statistics. 